\title{
Application of renewable and alternative sources of energy in agricultural construction projects
}

\author{
Sophia Diakonova ${ }^{1, *}$, Lyudmila Shevchenko ${ }^{1}$, Elena Sharapova $^{1}$ \\ ${ }^{1}$ Voronezh State Technical University, 14, Moscow Avenue, 394026, Voronezh, Russia
}

\begin{abstract}
The paper clarifies the concepts of "renewable" and "alternative" energy, classifies alternative energy sources, summarizes their preference over traditional energy sources. The paper considers the issue of using wind power and solar energy as the most acceptable alternative energy sources for the construction of agricultural facilities. A detailed analysis of the strengths and weaknesses of the wind and solar installations applying was carried out.
\end{abstract}

\section{Introduction}

Renewable energy is the energy received from renewable energy sources (RES). RES are natural resources, amount of which either recover faster than it is used, or does not depend on the fact of using those resources [1]. The term "renewable" is rightly considered quite vague, it is opposed to the concept of "non-renewable", which means a source that can totally disappear during its use. For example, "non-renewable natural resources" in the current situation of their intensive use may disappear in the coming decades.

Alternative energy sources, as the authors consider, are such sources, energy of which differs from traditional sources with the use of hydrocarbon fuels, such as oil, natural gas and coal.

Since the above concepts often induce a confusion, it is necessary to give an explanation and provide a complete classification of alternative and renewable energy sources.

Firstly, there amount of alternative sources is more than of renewable sources.

Secondly, renewable sources comprise the major part of alternative energy sources.

Thirdly, alternative sources contain non-renewable sources, excluding the use of hydrocarbon resources.

Alternative energy includes:

1. Wind power.

2. Solar-power engineering (solar energy).

3. Biofuel:

- liquid (biodiesel, bioethanol, biomethanol);

- Solid (wood waste and biomass, such as wood chips, pellets (pellets) from wood, husk, straw, etc., fuel briquettes);

*Corresponding author: sof1355@yandex.ru 
- gaseous (biogas, synthesis gas).

4. Alternative hydropower:

- tidal power stations;

- wave power stations;

- mini and micro hydropower plants;

- Aero hydroelectric power station.

5. Geothermal power engineering:

- thermal power stations;

- ground heat exchangers.

6. Thunderstorm energy.

7. Controlled thermonuclear fusion.

8. Kinetic energy, as well as varieties of muscular and mechanical energies.

9. Hydrogen energy.

10. Space power engineering.

11. Waste management.

It stands to mention that not all the listed alternative energy sources are possible to use in high-rise construction projects. The most applicable ones are wind energy and solar energy, although the supply of electricity and heat is not excluded almost from any of the listed sources in case of their availability and the existence of the appropriate infrastructure in the region.

Today alternative energy experiences good and prosperous times. In recent years, the prime cost of wind power has fallen by $61 \%$, the prime cost of solar electricity - by $82 \%$. Alternative fuel is getting cheaper at a high rate of speed [2].

Energy markets are developing under the strong influence of two factors:

1) The cost of electricity production with the use of renewable energy is constantly decreasing and no longer exceeds the cost of its generation by hydrocarbon generation.

2) The adoption of political and legislative decisions that stimulate the development of alternative and renewable energy and limit the use of traditional energy resources, comes from the deterioration of environmental conditions throughout the world.

\section{Materials and methods}

In the leading countries of the world, energy-saving technologies in high-rise construction appeared during the energy crisis of the 1970s. Since then, office buildings have been designed and built in accordance with the principles of environmental protection. Such environmentally friendly technologies include: high-quality thermal insulation, elaborated planning concepts, the use of renewable, alternative and clean energy sources, natural and non-toxic building and finishing materials, minimizing the negative impact of the building on the environment. The objects under construction are highly economical. An example is the 22-storey business center Manitoba Hydro Place in Winnipeg (Canada) consuming 70\% less energy than buildings of similar size due to energy-saving technologies, which saves about 480 thousand dollars a year [3].

For the construction and subsequent operation of high-rise buildings that meet modern requirements, it is necessary to create and use completely new energy sources that must meet the following requirements:

1. Have a low cost.

2. Be renewable.

3. Be autonomous.

4. Do not require long lines to carry energy.

5. Have a transition inside cities from the central sources of energy to local individual energy sources. 
6. Be environmentally friendly.

7. Give energy from hundreds of watts to hundreds of megawatts.

The main advantages of AES and RES over other sources of energy production are pointed out below:

1) Renewability (inexhaustibility) of resources is a significant advantage, because there is an urgent problem of the rapid exhaustion of organic natural energy resources. Such property as renewability is highly valued in modern civilization, which stands on the verge of a complete shortage of traditional energy sources. By some accounts, the world will run out of petroleum reserves in 40 years, of natural gas approximately in 60 years. Therefore, renewability of energy enables changing over from traditional energy carriers, which are more expensive and difficult to access.

2) Environmental friendliness is an important aspect for the world's population. Today, the fact of the harmful influence on the environment of traditional energy-producing technologies (including nuclear and thermonuclear technologies) is well-known and proven. It is proved that their application inevitably leads to dramatic climate changes, which are expected to happen within the first decades of the 21st century. The yearly emissions of carbon dioxide (CO2) into the atmosphere due to the combustion of fuel (oil, gas and coal) lead to global warming.

3) Availability of non-traditional energy sources. Virtually all countries have the opportunity to use their own renewable energy sources. Use of renewable energy will ensure sustainable electricity and heat supply to remote settlements, freeing them from raw dependence, unstable fuel prices and high costs associated with transportation of fuel over long distances.

4) The economic aspect of the application of new types of energy is certainly important. Switching to alternative technologies in the energy sector will save the country's fuel resources for some industries. In addition, the cost of energy produced by many alternative sources is already lower than the cost of energy from traditional sources, and the payback period for the construction of alternative power plants is much less. The prices for alternative energy are declining, while the traditional ones are constantly growing.

5) The social reason for switching to alternative sources is important when using alternative energy. Under the conditions of the increasing population density, the evergrowing production of energy with the help of nuclear power plants, HPPs is not costeffective and safe for the environment. The European Union countries are abandoning the projects of the so-called "peaceful atom". For instance, Italy closed all the existing nuclear power plants and completely abandoned nuclear power, Belgium, Germany, Spain and Switzerland have a long-term policy to abandon nuclear energy, etc. There are well-known facts of the growth of cancer and other serious diseases in the areas of nuclear power plants, large hydropower stations, fuel and energy complex enterprises, the damage caused by giant flat hydropower plants, all this increases social tension.

6) Evolutionary-historical aspect consists in the fact that in connection with the limited fuel resources on the Earth, as well as with the increase of catastrophic changes in the atmosphere and the biosphere of the planet, the existing traditional energy appears to be not viable. For the evolutionary development of society, it is necessary to begin a gradual proceeding to alternative energy sources immediately.

7) Autonomy. If there is such a necessity, renewable sources can operate autonomously, providing energy to consumers that are not connected to centralized energy networks.

8) Security of supply, transportation and, of course, scientific and technological progress are the rest of incentives for the introduction of alternative energy sources. Constant updates, modern developments and innovations increase the competitiveness of alternative energy. 


\section{Results}

The economy of renewable energy in comparison with hydrocarbon energy is distinguished by short terms of design and construction, low (or decreasing) specific variables and capital expenses and cost of kilowatt-hours. In addition, the use of renewable energy largely removes the risks of long-term investment projects for the supply of electricity - especially solar and wind power plants, and the cost of their electricity does not depend on the leaps in the fuel market.

Since wind power and solar energy are recommended for the construction of high-rise buildings as the most applicable AEI, we will consider them in more detail. It should be noted that more and more projects are being implemented where combined systems are used that use both these AEs simultaneously, which only leads to an increase in the energy efficiency of such buildings.

Wind energy is a branch of energy that specializes in converting the kinetic energy of air masses in the atmosphere into electrical, mechanical, thermal or any other form of energy convenient for use in the national economy.

Solar energy is one of the most promising areas of alternative energy, which receives thermal or electric energy due to solar radiation.

High-rise buildings are distinguished by a wide variety of facades, which are influenced by various factors. An important criterion in the drafting of a skyscraper is the wind load, until recently bringing only problems to architects. For example, negative moments when exposed to winds in high-rise buildings were: noise from the twists of the air, resonance and tangible variations in structures, penetration of air flows into the building. The higher the building, the higher the wind speed and at an altitude of 100 meters the speed increases about two times [4].

AES became the most frequently applied in high-rise construction of Asian countries (Taiwan, South Korea, China, India, etc) [5], where in connection with overpopulation, advanced high-rise buildings provided with innovative technologies are erected in present times.

The roof of the building "Energy Flower" in the Chinese city of Wuhan has the shape of a 140 meter "Flower of Calla". The skyscraper is zero-energy. One of the elements of the building providing energy is the roof, which is a bowl, the surface of which consists of solar receivers for generating electricity. The roof surface is also suitable for collecting rainwater, which can be used for building water supply after appropriate treatment. In addition, the center of the flower represents the vertical axis of the wind turbine, which also generates energy. Thus, the building uses various modern innovative achievements - it is the accumulation of solar energy, wind power generation and processing of rainwater.

For the fuller reception and replenishment of energy in recent times, the shapes of skyscrapers (China, 2011, the Pearl River building) have even been designed for windbreakers with special wind tunnel tunnels, while their convex-concave facade surfaces serve to maximize catching the sun's rays [6].

Today wind turbines have reached a level of commercial maturity and can compete with traditional sources of electricity in places with favorable wind speeds. Wind power has both strengths and weaknesses, shown in Table 1.

Table 1. Strengths and weaknesses of wind power.

\begin{tabular}{|l|l|}
\hline \multicolumn{1}{|c|}{ Strengths of wind power } & \multicolumn{1}{c|}{ Weaknesses of wind power } \\
\hline $\begin{array}{l}\text { 1. Wind energy is referred to renewable } \\
\text { energy }\end{array}$ & $\begin{array}{l}\text { 1. Inconsistency: this factor is the risk of not getting } \\
\text { the right amount of electricity. In some parts of the } \\
\text { land, wind power may not be enough to generate the } \\
\text { required amount of electricity }\end{array}$ \\
\hline
\end{tabular}




\begin{tabular}{|c|c|}
\hline $\begin{array}{l}\text { 2. Wind power is a rapidly growing } \\
\text { industry }\end{array}$ & $\mathrm{No}$ \\
\hline $\begin{array}{l}\text { 3. Unlike fossil fuels, wind energy is } \\
\text { almost inexhaustible, universally } \\
\text { available and more environmentally } \\
\text { friendly. There are hundred times more } \\
\text { wind energy reserves than the reserves } \\
\text { of hydropower of all the rivers of the } \\
\text { planet }\end{array}$ & $\begin{array}{l}\text { 3. High cost: } \\
\text { - the cost of the inverter is } ~ 50 \% \text { of the cost of the } \\
\text { whole installation. } \\
\text { - The cost of batteries is about } 25 \% \text { of the cost of } \\
\text { installation. } \\
\text {-to ensure reliable power supply to such an } \\
\text { installation, a diesel generator is sometimes added, } \\
\text { comparable in price to the whole installation }\end{array}$ \\
\hline $\begin{array}{l}\text { 1. Fuel economy. Wind generators do } \\
\text { not consume fossil fuels during } \\
\text { operation. The work of a wind } \\
\text { generator with the capacity of } 1 \mathrm{MW} \\
\text { for } 20 \text { years allows to save } \\
\text { approximately } 29 \text { thousand tons of coal } \\
\text { or } 92 \text { thousand barrels of oil }\end{array}$ & $\begin{array}{l}\text { 4. Conditionally low output of electricity: wind } \\
\text { generators are significantly inferior in generating } \\
\text { electricity to diesel generators, which leads to the } \\
\text { need to install several turbines at once. It should be } \\
\text { taken into account that wind turbines are ineffective } \\
\text { at peak weights }\end{array}$ \\
\hline $\begin{array}{l}\text { 5.Unlike traditional thermal power } \\
\text { plants, wind power plants do not use } \\
\text { water, which allows to reduce } \\
\text { consumption of water resources }\end{array}$ & $\begin{array}{l}\text { 5. Danger to wildlife: rotating turbine fans pose a } \\
\text { potential hazard for some species of living organisms. } \\
\text { According to statistics, the fans of each installed } \\
\text { turbine are the prerequisite for the death of at least } 4 \\
\text { birds per year }\end{array}$ \\
\hline $\begin{array}{l}\text { bine reduces the } \\
\text { tons of } \mathrm{SO} 2,4\end{array}$ & $\begin{array}{l}\text { 6. Low-frequency vibrations trans } \\
\text { soil cause a tangible chatter of win } \\
\text { a distance of up to } 60 \mathrm{~m} \text { from the } \mathrm{w} \\
\text { megawatt class }\end{array}$ \\
\hline $\begin{array}{l}\text { 7. Ergonomics. Wind power stations } \\
\text { take up very little space and simply fit } \\
\text { into any landscape, and also inimitably } \\
\text { mix with other types of economic use } \\
\text { of territories }\end{array}$ & $\begin{array}{l}\text { 7. Wind turbines remove some of the kinetic energy } \\
\text { of moving air masses, which leads to a decrease in } \\
\text { the speed of their movement. With the massive use of } \\
\text { wind turbines (for example, in Europe), this } \\
\text { slowdown theoretically can have a significant effect } \\
\text { on local (and even global) climatic conditions of the } \\
\text { terrain. Reducing the average wind speed can make } \\
\text { the region's climate more continental due to the fact } \\
\text { that slowly moving air masses manage to heat up } \\
\text { more in summer and cool in winter }\end{array}$ \\
\hline $\begin{array}{l}\text { 8. Wind power is } t \\
\text { places difficult of } \\
\text { wind generators ca } \\
\text { cheaper solution for }\end{array}$ & $\begin{array}{l}\text { the blades: during the operation of wind } \\
\text { winter under high humidity conditions, ice } \\
\text { the blades may form. When starting the } \\
\text { ne, dispersion of ice on a considerable } \\
\text { possible }\end{array}$ \\
\hline
\end{tabular}

The most rational way of obtaining energy is the transformation of solar radiation, as an inexhaustible source of energy. The amount of solar energy received by the Earth in a week is much more than all the reserves of oil, gas, coal and uranium on the planet. The energy of the sun can be widely spread in our country. In many areas of Siberia and in the south of the country, the number of sunny days per year can reach three hundred. These indicators can be compared with the climatic condition of Southern Europe, where solar energy is very popular. Today, a peak number of efficiency of solar stations (about $40 \%$ ) belongs to the USA. In theory, the efficiency is $87 \%$ [7, 8].

Solar installations can be classified in such a way: solar concentrators, solar parabolic cylindrical concentrators, solar disk type plants, solar power plants of a tower type with a central receiver, solar "ponds", solar balloon power stations.

Designers, taking into account the growing popularity of solar installations, offer designs of buildings whose facades entirely consist of solar panels. So, the building, which 
has 240 square meters. $m$ will be able to reduce energy consumption by $40 \%$ for air conditioning and the same for heating.

Modern technology allows installing in high-rise buildings not only solar panels, but also cheaper structures capturing solar energy - transparent plastic windows that serve as solar panels at the same time.

An analysis of the advantages and disadvantages of solar energy is given in Table 2 .

Table 2. Strengths and weaknesses of solar power.

\begin{tabular}{|c|c|}
\hline Strengths of solar power & Weaknesses of solar power \\
\hline 1. Sunlight is inexhaustible & $\begin{array}{l}\text { 1. The price of solar photovoltaics is } \\
\text { relatively high }\end{array}$ \\
\hline $\begin{array}{l}\text { 2. This source of energy is given to humanity } \\
\text { absolutely free of charge }\end{array}$ & $\begin{array}{l}\text { 2. Installation of solar panels requires a lot } \\
\text { of extra space. Solar batteries should be } \\
\text { periodically cleaned from dust and dirt. } \\
\text { Therefore, in the case of working with an } \\
\text { installation area of several square } \\
\text { kilometers with cleaning, considerable } \\
\text { difficulties can arise }\end{array}$ \\
\hline $\begin{array}{l}\text { 3. Solar energy is generally available, as the Sun } \\
\text { shines in the north and in the south, in the west } \\
\text { and in the east }\end{array}$ & $\begin{array}{l}\text { 3. The service life of solar batteries is } 30- \\
50 \text { years, so the problem of the subsequent } \\
\text { processing of modules arises, though the } \\
\text { solution of the problem of their utilization } \\
\text { has not been found yet }\end{array}$ \\
\hline $\begin{array}{l}\text { 4. The system does not require special } \\
\text { maintenance. Solar modules work automatically } \\
\text { and are easy to install and maintain }\end{array}$ & $\begin{array}{l}\text { 4. Large areas are required for installation } \\
\text { of solar panels }\end{array}$ \\
\hline 5. Noiselessness of solar energy production & $\begin{array}{l}\text { 5. In spite of the ecological purity of the } \\
\text { received energy, the photocells themselves } \\
\text { contain poisonous substances, for example, } \\
\text { lead, cadmium, gallium, arsenic, etc., and } \\
\text { their production consumes a lot of other } \\
\text { dangerous substances }\end{array}$ \\
\hline 6. Safety of solar energy production & $\begin{array}{l}\text { 6. Inconsistency of the daily cycle. Some } \\
\text { solar systems are not able to work at night, } \\
\text { in the evening the efficiency of stations } \\
\text { falls by several times. }\end{array}$ \\
\hline $\begin{array}{l}\text { 7. Solar systems provide additional assistance to } \\
\text { rural areas (especially in places where other } \\
\text { electricity is not available). Lighting the house, } \\
\text { providing a cooling system or the necessary } \\
\text { hospital heat and pumping water into a water } \\
\text { tower are the small part of the scope }\end{array}$ & 7. Solar panels can be damaged by hail. \\
\hline $\begin{array}{l}\text { 8. Systems can cover roofs and facades, help in } \\
\text { reducing the energy costs of a building. They do } \\
\text { not produce vibration and can be integrated in } \\
\text { various aesthetically acceptable ways }\end{array}$ & $\begin{array}{l}\text { 8. Lack of technology and resources for } \\
\text { own production }\end{array}$ \\
\hline $\begin{array}{l}\text { 9. The time of the energy recoupment of the } \\
\text { modules is constantly decreasing. For instance, } \\
\text { the time required for the payback of the solar } \\
\text { battery module is very small; it varies from } 1.5 \text { to } \\
3 \text { years. }\end{array}$ & \\
\hline
\end{tabular}

In Russia, the population is much more difficult to switch to alternative energy sources. Despite the increase in prices for electricity and other utilities, it is difficult to replace the usual way of life with a more modern one, although this experience is widely used in 
foreign countries: individual buildings, solar and wind villages, and many other examples. The main problem is the lack of technology and resources for own production. The analysis shows the main reason for the inadequate use of solar installations in Russia. This is their high cost, decrease in which makes one expect the increase in the demand for both construction enterprises and the population for individual construction. Therefore, today batteries are more expensive than solar power plants themselves. The difficulties are attributed to the fact that part of the equipment of solar stations has to be purchased abroad)

\section{Discussion}

There are many reasons for developing alternative and renewable energy, but the most significant ones are environmental security and energy self-sufficiency. However, the instability in power producing does not let domestic enterprises reach the level of industrial consumption.

In Russia, large corporations are not ready yet to switch over to renewable energy sources, even partly, for meeting their demand for electricity. The government decided that the share of green energy should reach $2.5 \%$ by 2020 . Investors in solar energy received the most favorable conditions: $60 \%$ of quotas were played. The share of quotas for wind energy development is $4 \%$. Stations using hydropower, peat, landfill gas, biogas or biomass are also not very popular among financiers.

Developed science and technological industrial production in combination with affordable financing allow not only to create competitive energy alternatives, but also to receive high profits from a growing market of renewable energy sources, the potential capacity of which is even greater than that of raw materials market.

\section{Conclusion}

Renewable and alternative energy sources have become widely recognized and widespread in recent years. This is due to the adoption of a number of political and legislative decisions dictated by the deterioration of the ecological situation of the planet, the growing cost of fossil fuels, social tension in several countries, and the exhaustion of natural resources.

The paper clarifies the concepts of "renewable energy" and "alternative energy", because the existing characterizations are quite vague. The authors give a classification of alternative energy sources, some of which are renewable energy sources.

The authors pointed out the following main advantages of alternative and renewable energy sources over other sources of energy: environmental friendliness, accessibility, economy, autonomy, transportation safety, social significance, etc.

Constant updates, modern developments and innovations increase the competitiveness and development rates of alternative energy.

The analysis of possible options of existing alternative energy sources educed the most suitable for the construction of high-rise buildings and structures: wind power and solar energy. The most rational way of obtaining energy is the transformation of solar radiation, as an inexhaustible source of energy.

The analysis of pros and cons of using wind energy and solar energy became the important part of the present work. The main problem of using alternative and renewable energy sources in Russia is the lack of technology and resources for own production, as well as high costs of solar power plants. 


\section{References}

1. V. Kankhva, IOP Conf. Series: Earth and Environmental Science 90, 012175 (2017) doi:10.1088/1755-1315/90/1/012175

2. A.V. Kozlov, Kontrol' vliyaniya parametrov atmosfery na ehnergeticheskie harakteristiki kremnievoj solnechnoj batarei, dis. kand. tekhn. nauk (Tom. politekhn. un-t, Tomsk, 2008)

3. S.N. D'yakonova, D.N. Kaz'mina, Nauchnyj Vestnik VGASU, Innovacii v stroitel'stve 3 (2017)

4. E. Nezhnikova, IOP Conf. Series: Earth and Environmental Science 90, 012161 (2017) doi:10.1088/1755-1315/90/1/012161

5. A. Zaychenko, S. Gutman, O. Kalinina, Advances in Intelligent Systems and Computing 692, 453-462 (2018) DOi - 10.1007/978-3-319-70987-1_48

6. I.V. Ilin, A.I. Levina, O.Yu. Iliashenko, Advances in Intelligent Systems and Computing 692, 1214-1223 (2018) DOi -10.1007/978-3-319-70987-1_130 